\title{
Checklist of mangrove snails (Mollusca: Gastropoda) in South Coast of Pamekasan, Madura Island, East Java, Indonesia
}

\author{
R. ADHARYAN ISLAMY ${ }^{1, \boldsymbol{v}}$, VERYL HASAN ${ }^{2, v v}$ \\ ${ }^{1}$ Departement of Aquaculture, Faculty of Fisheries and Marine Science, Universitas Brawijaya. Jl. Veteran No. 16, Malang 65145, East Java, Indonesia \\ Tel.: +62-341-553512, Fax.: +62-341-556837, "email: r.adhariyan@ub.ac.id \\ ${ }^{2}$ Department of Fish Health Management and Aquaculture, Faculty of Fisheries and Marine Science, Airlangga University. Jl. Mulyosari, Surabaya \\ 60113, East Java, Indonesia. Tel.: +62-31-5911451, "email: veryl.hasan@fpk.unair.ac.id
}

Manuscript received: 23 April 2020. Revision accepted: 17 June 2020.

\begin{abstract}
Islamy RA, Hasan V. 2020. Checklist of mangrove snails (Mollusca: Gastropoda) in South Coast of Pamekasan, Madura Island, East Java, Indonesia. Biodiversitas 21: 3127-3134. Mangrove forests are crucial to gastropods providing breeding and nursery grounds, food sources, and shelter from predators. They are useful bioindicators of environmental pollution. Consequently, it is crucial to understand the species richness of gastropods mangrove environments. This study aims to provide information about the species composition of mangrove snails in the South Coast of Pamekasan (Madura Island), East Java, Indonesia. Samplings were performed at low tide from 4 stations in December 2019 using a transect $(10 \mathrm{~m} \times 10 \mathrm{~m})$. All samples were identified using reference books and published journal. We found a total of 10 family consist of Assimineidae, Cerithiidae, Ellobiidae, Littorinidae, Muricidae, Neritidae, Olividae, Planaxidae, Potamididae, and Trochidae with consist of 15 Genus, i.e., Assiminea, Clypeomorus, Cerithium, Rhinoclavis, Laemodonta, Littorarina, Tenguella, Semiricinula, Nerita, Clithon, Oliva, Planaxis, Pirenella, Telescopium, and Monodonta. The most common substrate where mangrove snails were found was rocks, sandy, and around the tree and roots of mangrove. All gastropods in this study found alive during our surveys and predominantly mangrove associated. We assume that there are still many snails that have not been surveyed at the location. We suggest to the future researcher to survey through different sampling efforts and sampling methods such as quantitative or semi-quantitative methods.
\end{abstract}

Keywords: Checklist mollusca, gastropods, Madura, mangrove snail, Pamekasan Coast

\section{INTRODUCTION}

Gastropods are unique from an ecological perspective because they are inhabiting extremely contrasting habitats (Marshall et al. 2015) such as marine, freshwater, and terrestrial environments [although they are predominantly marine] compared to other more abundant metazoans (Dayrat et al. 2011; Webb 2012). Gastropods play a significant ecological role in nutrient dynamics in the mangrove ecosystem because they form an essential link within the food web as predators, herbivores, detritivores, and filter feeders (Pawar 2012; Suresh et al. 2012). They are useful for bioindicators of environmental pollution (ElSorogy et al. 2013). The diverse group of gastropods plays an important role in the benthic food web (Adams and Crawley 2018).

Ecologically, mangrove forests are important as feeding ground, breeding ground and nursery ground for various types of terrestrial and marine organisms (Igulu et al. 2014; Shing et al. 2014). Mangrove forests are crucial to gastropods providing breeding and nursery grounds, food sources, and shelter from predators (Reid et al. 2010). However, there were several factors causes of the disturbances in the mangrove area, i.e., economic factors and the lack of people understanding the importance of the ecology of mangrove forests, leading to the destruction of mangroves for economic purposes. (Chatarina et al. 2011).
The mangrove ecosystem in the South Coast of Pamekasan, chosen because of its vital role for local communities. Local people harvest shrimp, snail, clam, crab, and several types of fish from this location as a livelihood for household needs. Nevertheless, now the mangrove ecosystem in this location has significant natural and artificial changes. The dynamics of sedimentation, abrasion, and the rate of change of land-use in the South Coast of the Pamekasan Regency are higher compare to the North Coast of Madura. Besides, the geographical position of the South Coast of Pamekasan Regency which is a crossing of Madura from Bangkalan to Sumenep increases the dynamics of population activities including reclamation of coastal land for new settlements, excavation of sand for building materials, felling of mangrove trees for timber and leaves for fodder (Suprakto 2005). It can endanger the life of mangrove biota, especially mangrove snails.

Consequently, it is crucial to understand the species richness and relative abundance of gastropods mangrove environments considering gastropods diversity is declining vastly worldwide (Nützel and Hausmann 2016). Moreover, there has not been much research on gastropods in the Madura region, especially Pamekasan. This study aims to provide information about the species composition of mangrove snails in the South Coast of Pamekasan, East Java, Indonesia. 


\section{MATERIALS AND METHODS}

\section{Sampling and identification of mangrove snail}

Samplings were performed at low tide from 4 stations (Figure 1) every week for one month in December 2019 (the beginning of the rainy season) using a transect (10m $x$ $10 \mathrm{~m}$ ) modification method of the published journal (Isroni et al. 2019). Determination of the observation station based on differences in land use (Figure 1). All gastropod samples placed in the sample box and preserved immediately in 5-7\% neutralized formalin. All samples were identified using reference books such as Abbott and Dance (2000); Tapilatu and Pelasula (2012); Arbi (2014); Dolorosa and Gallon (2014); Reid (2014); Reid and Claremont (2014), and Baharuddin and Marshall (2015).
Gastropod identification is made by observing morphological characteristics such as shell shape, shell width, shell length, shell color, apex, whorl, body whorl, siphonal canal, spire, suture, aperture, and columella. After being identified, the sample is measured using a vernier caliper, taken using a digital camera, and then stored again in a collection bottle. The data obtained will be analyzed by describing the morphological characteristics based on the reference book.

\section{Study of area}

Determination of the observation station based on differences in land use. A complete description of the sampling station shown in Figure 1 and table 1.

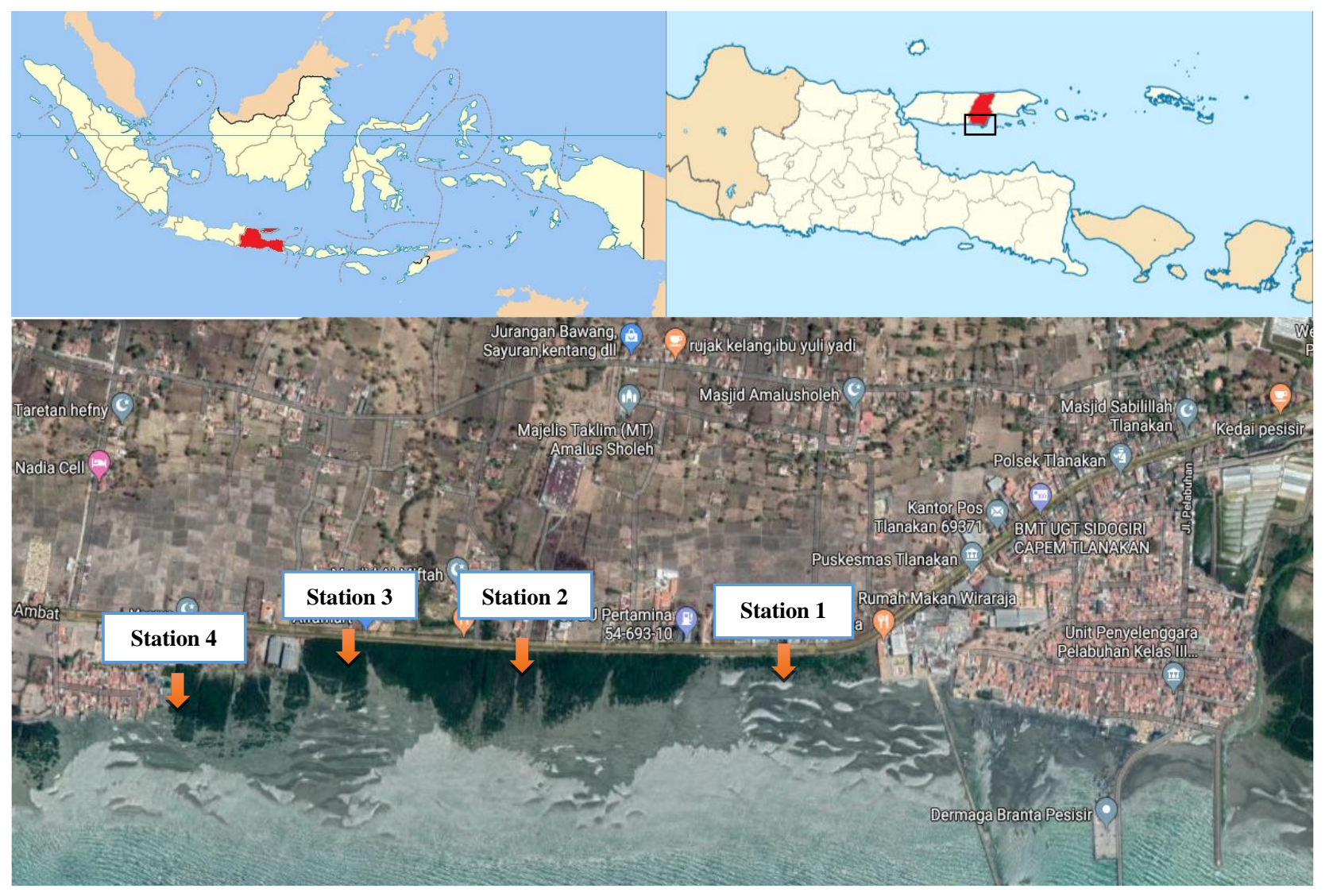

Figure 1. Map of sampling location in Pamekasan District, Madura Island, East Java Province, Indonesia (above); and map of the South Coast of Pamekasan, showing the location of sampling stations (below). Note: Arrows indicated sampling locations.

Table 1. Coordinates, type of subtracts, type of mangrove vegetation and description of the sampling station

\begin{tabular}{|c|c|c|c|c|}
\hline $\begin{array}{c}\text { Station } \\
\text { name }\end{array}$ & Coordinates & $\begin{array}{c}\text { Substrates } \\
\text { type }\end{array}$ & Vegetation & Description \\
\hline Station 1 & 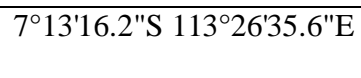 & Sandy mud & Rhizophora (stake) & $\begin{array}{l}\text { Close to the salt warehouse, a newly planted } \\
\text { mangrove area }\end{array}$ \\
\hline Station 2 & $7^{\circ} 13^{\prime} 15.7^{\prime \prime S ~ 113^{\circ} 26} 24.0^{\prime \prime} \mathrm{E}$ & Sandy mud & Rhizophora, Avicennia & $\begin{array}{l}\text { It is a river mouth, close to the rest area and } \\
\text { gas station }\end{array}$ \\
\hline Station 3 & $7^{\circ} 13^{\prime} 15.9^{\prime \prime S} 113^{\circ} 26^{\prime} 01.6^{\prime \prime} \mathrm{E}$ & Mud & $\begin{array}{l}\text { Rhizophora, Avicennia, } \\
\text { Bruguiera }\end{array}$ & River mouth \\
\hline Station 4 & $7^{\circ} 13^{\prime} 19.2^{\prime \prime S} 113^{\circ} 25^{\prime} 49.6^{\prime \prime} \mathrm{E}$ & Sandy mud & Rhizophora (tree) & Close to residential areas \\
\hline
\end{tabular}




\section{RESULTS AND DISCUSSION}

\section{Mangrove snails found at the study site}

In this study, we found a total of 10 families (Table 2) consist of Assimineidae, Cerithiidae, Ellobiidae, Littorinidae, Muricidae, Neritidae, Olividae, Planaxidae, Potamididae, and Trochidae with consist of 15 Genera, i.e., Assiminea, Clypeomorus, Cerithium, Rhinoclavis, Laemodonta, Littorarina, Tenguella, Semiricinula, Nerita, Clithon, Oliva, Planaxis, Pirenella, Telescopium, and Monodonta. A total of 7 genera were found in station 1 (Clypeomorus, Littorarina, Semiricinula, Nerita, Clithon, Oliva, and Telescopium). Total of 13 Genera found in station 2 (Assiminea, Clypeomorus, Cerithium, Rhinoclavis, Laemodonta, Littorarina, Tenguella, Nerita, Clithon, Planaxis, Pirenella, Telescopium, and Monodonta). Total of 13 Genera found in station 3 (Assiminea, Clypeomorus, Rhinoclavis, Laemodonta, Littorarina, Semiricinula, Tenguella, Nerita, Clithon, Oliva, Planaxis, Pirenella, and Telescopium). Total of 9 Genera found in station 4 (Assiminea, Clypeomorus, Cerithium, Littorarina, Semiricinula, Nerita, Clithon, Pirenella, and Monodonta).

In this study, species richness of gastropods inhabiting mangrove forest in station 2 (13 genera) and Station 3 (13 genera) is highest and lowest in Station 1 (7 genera).

We found the highest family richness of gastropods from collections on vegetation such as on vegetation of Rhizophora, Bruguiera, and Avicennia in leaves, stem, branches, and roots. In this study, the family of Neritidae was found at almost all stations. The second highest is Cerithiida.

\section{The checklist}

\section{Family of Assimineidae}

Assiminea Figure 2.A (Zvonareva and Kantor 2016: 409, Figure 7G-H). Assiminea is one of the most abundant and representative benthic invertebrates (Suzuki et al. 2002). They are gastropods in the family Assimineids (Zvonareva and Kantor 2016). In this study, they commonly found on mud bottom of the lower estuarine mangals and also on mud surface under mangrove trees. Average shell length ranged from 4.73 to $5.74 \mathrm{~mm}$, and size structures showed different patterns among the stations (Suzuki et al. 2002). In this study, they commonly found in the coastal mudflat near the mangrove tree of Avicennia alba.

\section{Family of Cerithiidae}

Clypeomorus 1 Figure 2.C (Zvonareva and Kantor 2016: 409, Figure 7E-F). Clypeomorus 2 Figure 2G (Zvonareva and Kantor 2016: 409, Figure 7A-B). Clypeomorus are epifaunal species in intertidal, estuarine, mangrove habitats, on the muddy or sandy substrate between pneumatophores of Avicennia and bare mud in near of the mangrove fringe. All the recorded Clypeomorus are common in shallow water and intertidal areas, and they are herbivores (Soekendarsi 2019). In this study, this genus found in the mangrove habitat of Avicennia. Deposit feeder lives in areas of high organic content. Stomach contents consist of microalgae, filamentous algae, macroalgae, vascular plant material, and diatoms comprising detritus in this habitat (Houbrick 1992).

Cerithium Figure 2.L (Zvonareva and Kantor 2016: 409, Figure 7I-J). Published study (Sun and Zhang 2014) describes that this snail has an elongated shell, turreted, comprising about 11 straight-sided whorls. Shell up to $25.82 \mathrm{~mm}$ in length and $9.42 \mathrm{~mm}$ in width. Protoconch and sharp apex commonly eroded. Early teleoconch elongate, sculptured with two spiral cords gradually becoming bearded. Adult teleoconch whorls sculptured with three major distinct beaded spiral cords. Beads on spirals aligned with axial ribs. Former varices randomly distributed. Axial ribs are usually indistinct. Suture clear, impressed. Body whorl sculptured with six or seven spiral cords, and the three posteriors beaded. Distinct varix opposite outer lip of aperture. Aperture fusiform, narrow. Columella concave with moderate callus and columellar lip. Anterior siphonal canal short, broad, slightly reflected. Anal canal clear, flanked by distinct parietal columella callus and tooth. Outer lip thick at the edge, crenulate, and with inner elongate denticles and a wide posterior sinus. Shell color black to light grey, sometimes with whitish stripes. Outer lip sometimes white. Operculum light brown, thin, corneous, and ovate with an eccentric nucleus.

In studied sites, it was found on mud under mangrove trees. They commonly found on intertidal mudflats from mid to low tide level, and beneath mangrove trees in nondrying puddles, in coastal estuarine mangroves (Zvonareva and Kantor 2016). Often co-occurs with Pirenella cingulate (Reid and Ozawa 2016). Development with the planktonic phase of 10 to 12 days (Ozawa et al. 2015).

Table 2. This type of mangrove snail was found at four research stations

\begin{tabular}{|c|c|c|c|c|c|}
\hline \multirow{2}{*}{ Family } & \multirow{2}{*}{ Genus } & \multicolumn{4}{|c|}{ Station } \\
\hline & & 1 & 2 & 3 & 4 \\
\hline Assimineidae & Assiminea & - & + & + & + \\
\hline \multirow[t]{4}{*}{ Cerithiidae } & Clypeomorus 1 & + & + & + & + \\
\hline & Clypeomorus 2 & + & + & + & + \\
\hline & Cerithium & - & + & - & + \\
\hline & Parvanachis & - & + & + & - \\
\hline Ellobiidae & Laemodonta & - & + & + & - \\
\hline Littorinidae & Littoraria & + & + & + & + \\
\hline \multirow[t]{2}{*}{ Muricidae } & Tenguella & + & - & + & + \\
\hline & Semiricinula & - & + & + & - \\
\hline \multirow[t]{2}{*}{ Neritidae } & Nerita & + & + & + & + \\
\hline & Clithon & + & + & + & + \\
\hline Olividae & Oliva & + & - & + & - \\
\hline Planaxidae & Planaxis & - & + & + & - \\
\hline \multirow[t]{2}{*}{ Potamididae } & Pirenella & - & + & + & + \\
\hline & Telescopium & + & + & + & - \\
\hline Trochidae & Monodonta & - & + & - & + \\
\hline
\end{tabular}




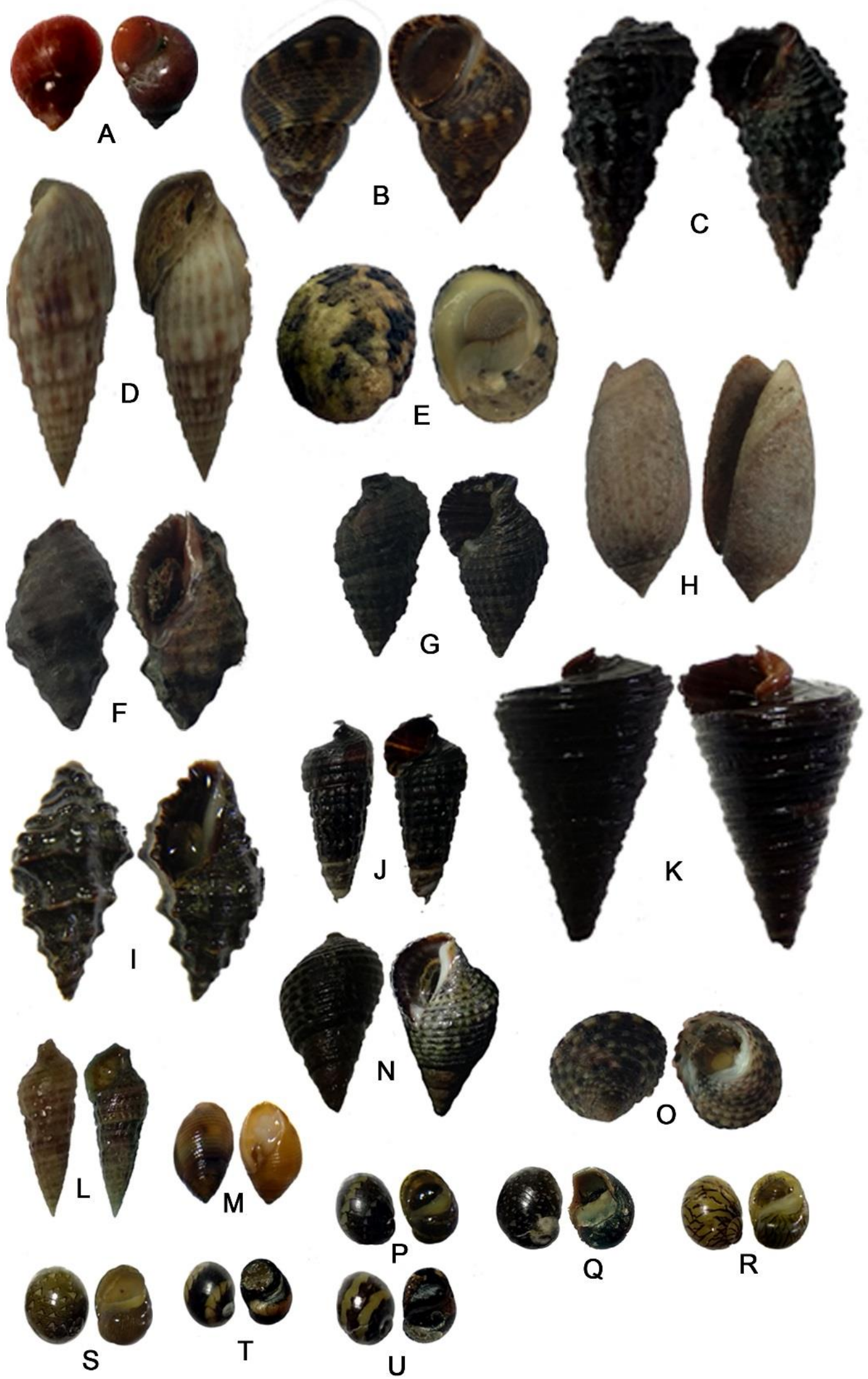

Figure 2. Mangrove snail in South Coast of Pamekasan-East Java. A. Assiminea (3mm); B. Littoraria (17mm); C. Clypeomorus 1 (26mm); D. Parvanachis (29mm); E. Nerita; F. Tenguella (19mm); G. Clypeomorus 2 (14mm); H. Oliva (23mm); I. Semiricinula (24mm); J. Pirenella (13mm); K. Telescopium (43mm); L. Cerithium (12mm); M. Laemodonta (3mm); N. Planaxis (16mm); O. Monodonta (12mm); P-U. Clithon (3mm) 
Rhinoclavis Figure 2.D (Okutani 2000: 120-121, Figure 36; Zvonareva and Kantor 2016: 409, Figure 7K-L). Rhinoclavis are deposit-feeding gastropods in coral-reefflat sediments. According to a published article (Janssen et al. 2011), the habitat of Rhinoclavis is Sand between coral patches and sand with seagrass, from 1 to $20 \mathrm{~m}$, mostly below $10 \mathrm{~m}$. Some specimens colonized by solitary corals. The Conservative position of corals on the backside of the shells may suggest that the coral colonized the gastropods during the lifetime. Cerithiid gastropods of the genus Rhinoclavis are among the most abundant mollusks in sediments at One Tree Reef, on the southern Great Barrier Reef. They herbivores snail (Soekendarsi 2019). Despite being microphages deposit-feeders, these snails reach their greatest abundances in coarse, sandy sediments on a shallow, subtidal sandflat, a habitat usually considered to be a typical for deposit-feeding infauna.

\section{Family of Ellobiidae}

Laemodonta Figure 2.M (Okutani 2000: 816-819, figure 11; Poppe 2010: 452, figure 5; Zvonareva and Kantor 2016: 409, figure $8 \mathrm{~W}-\mathrm{X}$ ). This snail commonly found in estuaries in mangrove areas and under rotting wood in salt marshes (both in the tidal zone and above usual high tide mark) (Zvonareva and Kantor, 2016). In the study, it was found on mud surface under mangrove trees. All of the Ellobiidae are air-breathing and hermaphroditic snails. The shell of one species (Laemodonta punctatostriata, $5 \mathrm{~mm}$ ) is distinctive in having spiral rows of tiny pits on the shell (hence its Latin name); They can be seen grazing algae on dead logs and stiff mud on the mangrove floor during daytime low tides; Its close relative, $L$. siamensis, is a slightly larger species $(7-8 \mathrm{~mm})$ that is common on soft wet mud (Ng and Sivasothi 2002).

\section{Family of Littorinidae}

Littoraria Figure 2.B (Zvonareva et al. 2015: 8, Figure 4C; Zvonareva and Kantor 2016: 409, Figure 6W-X). The previous study describes that Littoraria includes to ovoviviparous animal base on the reproductive apparatus, between the size of the oviduct and prostate concerning the shell height is a positive correlation (Zeidan et al. 2019). In studied sites, it was found on trunks and roots of mature Rhizophora trees. Littoraria predominantly mangroveassociated and typically life on trunks and roots throughout Rhizophora forest, occasionally on other trees (0.3-2 m above the ground) (Zvonareva and Kantor 2016). Rather common on sheltered rocks (Reid and Ozawa 2016). The general distribution of this genus is throughout the tropical and subtropical Indo-Pacific (Reid and Ozawa 2016). The external morphology of the shell presented typical turbinate shape, with fine texture, but robust and with a sharp vertex. Color polymorphism was observed, including beige, brown, yellow-orange, and purple, with dark brown predominating (Zeidan et al. 2019).

\section{Family of Muricidae}

Tenguella Figure 2.F (Zvonareva et al. 2015: 9; Zvonareva and Kantor 2016: 409, Figure 8C-D). The muricid whelk Tenguella is common on the low and mid intertidal rocky shores (Wright et al. 2018). The distribution and abundance of this genus are patchy and variable within and among shores. Significant influences on its distribution and abundance include emersion, wave exposure, competitor abundance, and the availability of suitable prey species. Tenguella marginalba has been found on areas of the shore with strong wave exposure, and favor the edges of rock pools and crevices (Coulson et al. 2011). Muricidae dwells on bare mud bottom associated with outer to mid estuarine mangroves (Lozouet and Plaziat 2008). Appears to be generally rare over its wide range (Reid and Ozawa 2016). In studied sites, it was found on the mud surface under mangrove trees and roots.

Semiricinula Figure 2.I (Tan and Liu 2001: 1279, Figure 1E-F). Semiricinula snail belongs to the neogastropod family Muricidae includes a diverse set of radular bauplan, including a beaked, three-dimensional form, a flattened-pentacusped form, and a third "dagger" type in which the central rachidian cusp is massive and elongate (Herbert et al. 2007). The published study about describes that Semiricinula neither pose bisulcate transverse groove nor the revolving raised ridges of small nodules equidistantly on the body whorl; Spire made up of 4-5 angulated whorls, body whorls with two spiral rows of compressed tubercles (9-11 in numbers), and two rows of indistinct ridges, anal sulcus broad inverted ' $U$ ' shape margined by a ridge; Inside of outer lip with 4-8 strong ridges, generally, six, arranged in pairs. Anterior canal short and broadly open; Colour: Light brown, interior white, dark blotches on columella; A deep ' $\mathrm{V}$ ' shape notch between inner lateral denticle and the central cusp of radula; The central cusp pointed and slightly curved towards the right side; Six small pointed denticles between marginal and lateral cusp (Kumar et al. 2017). They commonly found in Intertidal rocky bottom or coral reef because they are Scavenger (Okutani 2000). In studied sites, it was found on rocks in the lowest part of the intertidal zone.

\section{Family of Neritidae}

Nerita Figure 2.E (Tan and Clements 2008:484, Fig. 2.11-12; Vermeij et al. 2009: 65, fig 7-8). Nerita included to family Neritidae. They are small to medium-sized euryhaline gastropods widely distributed from marine to freshwater habitats (Tudu et al. 2017). They are herbivores inhabiting in the middle to upper intertidal zones. Shells are low spired with a swollen last whorl and D-shaped calcareous operculum. The heavy shell is to resist desiccation and to protect from predators. Nerita snail grows up to $10 \mathrm{~mm}$ and ecological notes that they developed with free-swimming veliger (Fukumori and Kano 2014). They found in estuaries, which does not extend to low salinity estuarine upper reach (Fukumori and Kano 2014). In this study, we found this snail on the sediment surface in the upper intertidal zone.

Clithon 1 Figure 2.P-U (Zvonareva et al. 2015: 8, Figure 3(6); Zvonareva and Kantor 2016: 409, Figure 3MN; Baharuddin et al. 2019: 1148, Figure 3(22)). These 
snails are euryhaline; the genus Clithon prefers to live in estuarine and tasteless waters. They have a geographical distribution in Indo-Pacific waters (Abdou et al. 2015). At present, it is known that as many as 11 types of Clithon are found in Java (Mujiono 2016). Most of its members (6 types) do not have thorns on the shell and have a serrated groove on the column, whereas in group 2, all members have spines on the shell and do not have a groove on the column. All members have a slanted crescent-shaped mouth. Meanwhile, all members of group 2 have the last threads that are bulging and have shoulder shells. One function of the thorn in the conch shell is for the defense system. With thorns in the shell, it can make it difficult for snail predators such as fish to eat it. Clithon found in several habitats such as large rocky substrates, sandy, and soil that have a water temperature of $26^{\circ} \mathrm{C}$, a water $\mathrm{pH}$ of 7.4 (Suratno et al. 2020). Clithon bicolor is a type of snail that has the most extensive distribution, which can be found in 4 of 6 provinces in Java, and Banten Province has the highest number of snail species, 10 species, and then West Java has 9 species (Suratno et al. 2020). Young snails that live in calm waters, sometimes their shells have thorns, whereas, in adult snails that live in fast-flowing waters, these thorns can reduce or disappear. The absence of thorns, in this case, is related to defense against the water flow, the loss of thorns on the shell can reduce the power of water flow so that the chance of being carried away by the water is getting smaller.

\section{Family of Olividae}

Oliva Figure 2.H (Voskuil 2018: 40, Figure 50). Oliva shell is subcylindrical, convolute, smooth; spire short, sutures channeled. Aperture narrow, longitudinal, and notched at the base. The columella is obliquely striated. No operculum. Oliva is very smooth shells, shining, and prettily colored, and have no epidermis. They are distinguished from several characters, i.e., the cylindrical cone, a channel which separated the whorls of the spire, and the striae on the columella; from volute and Mitra, by the spiral whorls of those shells being separated by simple unchanneled suture. The Oliva is further distinguished by a prominent callus at the upper extremity of the columellar lip, which assist in forming the channel of the spire. At the base of the columella, some vestiges of the very oblique callus of the Ancillariae appear, but those shells never have their suture channeled, nor a striated columella. Species of the Olividae genus Agaronia, are characterized by their smooth elongate fusiform shell with a broad, glossy fasciola band at the anterior part of the body whorl that usually extends to over half the aperture height (Tan et al. 2019).

The shells of the olive are rolled around the longitudinal axis, leaving a void space at the place of the axis, and the last whorl so envelopes the rest, that only their upper portion is visible, and consequently the spire is concise. The shell appears to be formed of two separated layers of testaceous matter, like that of the Cypaea, for of we remove the exterior layer, we generally find the one beneath of a different color. Some 20 living species and subspecies are distributed in tropical and subtropical regions worldwide (Cilia 2012).

\section{Family of Planaxidae}

Planaxis Figure 2.N (Zvonareva et al. 2015: 8; Zvonareva and Kantor 2016: 409, Figure 4Q-R). Planaxis are epifaunal species in intertidal, estuarine, mangrove habitats, on muddy or sandy substratum between pneumatophores of Avicennia and on bare mud in front of the mangrove fringe. They are deposit feeder, lives in areas of high organic content. Planaxis usually live on the beach, where muddy rock substrates are an ideal habitat for Planaxis, so that these species can live in groups in large numbers (Pratama et al. 2011). A published study describes that the stomach of Planaxis contents consists of microalgae, filamentous algae, macroalgae, vascular plant material, and diatoms comprising detritus in this habitat (Houbrick 1992). The presence of mangroves is a critical factor in the distribution of this species. In studied sites, this genus was found on mud surface between pneumatophores of Avicennia and Rhizophora as well and on the sandbanks in mangrove stands.

\section{Family of Potamididae}

Pirenella Figure 2.J (Reid and Ozawa 2016: 30-35, Figures 1, 2G, H, 4I, 10, 11A; Zvonareva and Kantor 2016: 413, Fig. 5C-D). Members of the genus Pirenella are abundant inhabitants of intertidal sedimentary shores, often found in association with mangroves, on the continental margins of the western Pacific and Indian Oceans, and the eastern Mediterranean Sea. Pirenella has attracted some attention as an inhabitant of extreme environments, from brackish estuaries to hypersaline lagoons and inland lakes. Shell: moderate size (to $54 \mathrm{~mm}$ ); elongate; conical, fusiform, or pupiform. Sculpture of 3 spiral cords on spire whorls (another partly visible in suture) and numerous axial ribs; varices may be present on spire whorls; no columella fold; ventrolateral varix usually present (occasionally absent); aperture slightly to strongly flared and thickened, peristome weakly sinuous or planar, weak or strong basal projection of outer lip defining anterior canal, posterior canal sometimes forming wing-like projection; Radula: rachidian tooth broad, with 7-13 pointed cusps; lateral tooth with a delicate lateral extension (Reid and Ozawa. 2016). Pirenella was found on mud and sandstones with algal associations in the upper intertidal and mid-intertidal zones in mangrove plantation as well as in natural mangroves (Solanki et al. 2017). They like to prefer muddy habitat generally, but, during and summer, the monsoon mud was restricted to mangrove roots, so these snails were observed at the base of the mangroves (Shukla 2014).

Telescopium Figure 2.K (Strong et al. 2011: 46, figure 1L). Mangrove snails (Telescopium) live in brackish water on a muddy base substrate and are affected by tides (Radjasa et al. 2012). Telescopium has a thick, cone-shaped and striped shell; a blackish shell color, murky brown and there is also a purplish-brown; It has a range of $75-110 \mathrm{~mm}$ in length and 17-47 $\mathrm{mm}$ in width; the conch shell is conical, long, slender, and somewhat horizontal at the bottom (Adriman et al. 2020). The color of the shell is 
murky brown, purplish brown, and blackish brown, the outer layer of the shell is equipped with a very tight spiral line and has a curved inward path. The length of the shell ranges from $7.5-11 \mathrm{~cm}$. The size of a standard adult shell can reach 90-100 $\mathrm{mm}$ in size, but according to (Houbrick, 1992), the conch shell can reach $130 \mathrm{~mm}$.

This organism is generally found under mangrove trees with mud substrate and found in groups. Currents and tidal waves do not readily carry this organism. T. telescopium has a thick shell structure that is useful for reducing evaporation so that it can adapt to high temperatures and is not quickly carried by currents and tidal waves.

\section{Family of Trochidae}

Monodonta Figure 2.O (Zvonareva et al. 2015: 8; Zvonareva and Kantor 2016: 409, Figure 2B-C). Morphologically, this species is characterized by a highly pointed apex and prominent granules on the spiral ribs. Shell color is highly variable, with a typically yellowish brown, greenish, or reddish background (Zhao et al. 2019). Found on sediment surface in the mid intertidal zone. Monodonta (Gastropoda: Trochidae) is a herbivorous snail that grazes on microalgae. Published study (Periyasamy et al. 2012) describes that Monodonta snail has the size of the shell varies between $15 \mathrm{~mm}$ and $43 \mathrm{~mm}$; Generally, it is heavy and thick and has an elongate-conical shape. It is whitish, tinged with grey, yellowish or greenish, spirally traversed by bands composed of alternating white and black purplish or red spots. The aperture is very oblique. The thick, smooth outer lip is beveled to an edge. It is pearly and iridescent within. The Columella is flattened on the face, bluntly lobed within, pearly, backed by an opaque white layer (Donald et al. 2012).

\section{Discussion}

Based on the diversity of genera found at the study site, we assume that the study site has rich mangrove snail even though the area of studied mangroves is small. For relative species diversity evaluation, we attempt to compare with published data. Comparison of relative richness and abundance of mollusks with other regional faunas is complicated due to several factors, some of which are difficult to evaluate. The most challenging factor in assessing was the completeness of the mangrove snail survey. We assume that there are still many snails that have not been surveyed at the location. Completeness surveys depending both on sampling effort and sampling methods such as quantitative and semi-quantitative methods (Sriaroon et al. 2005). Sampling methods are designed to match the aim of a given study. Thus it is inappropriate to compare species numbers from faunistic studies with numbers obtained (Hong 2004). Unfortunately, the published accounts do not always describe the methods of collecting in detail, thus complicating direct comparison.

In this study, we found a total of 10 families (Table 2) consist of Assimineidae, Cerithiidae, Ellobiidae, Littorinidae, Muricidae, Neritidae, Olividae, Planaxidae, Potamididae, and Trochidae with consist of 15 genus, i.e., Assiminea, Clypeomorus, Cerithium, Rhinoclavis, Laemodonta, Littorarina, Tenguella, Semiricinula, Nerita,
Clithon, Oliva, Planaxis, Pirenella, Telescopium, and Monodonta. The most common substrate where mangrove snails were found was rocks, sandy, and around the tree and roots of mangrove. All gastropods in this study found alive during our surveys and predominantly mangrove associated.

\section{REFERENCES}

Abbott TR, Dance SP. 2000. Compendium of Sea Shells (4th ed.). Odyssey Publishers, USA.

Abdou A, Keith P, Galzin R. 2015. Freshwater neritids (Mollusca: Gastropoda) of tropical islands: Amphidromy as a life cycle, a review. Rev Ecol 70: 387-397.

Adriman A, Sumiarsih E, Andriani N. 2020. Density of mangrove snail (Telescopium telescopium) in the mangroves ecosystem of Mengkapan Village, Sungai Apit Subdistrict, Siak District, Riau Province. IOP Conf Ser: Earth Environ Sci 430: 1-8.

Arbi UY. 2014. Taxonomy and Phylogeny of The Snail Family Potamididae (Gastropoda: Mollusk) in Indonesia Based on Morphological Characters. Bogor Agriculture Institute, Bogor.

Baharuddin N, Basir NHM, Zainuddin SNH. 2019. Tropical intertidal gastropods: Insights on diversity, abundance, distribution and shell morphometrics of Pulau Bidong, Malaysia. AACL Bioflux 12: 13751387.

Baharuddin N, Marshall DJ. 2015. Common Aquatic Gastropods of Brunei. University Brunei Darussalam, Brunei Darussalam.

Chatarina M, Ahmad SN, Trisni U. 2011. Model pemberdayaan masyarakat dalam pengelolaan dan pelestarian hutan mangrove di pantai Pasuruan Jawa Timur. Jurnal Manusia dan Lingkungan 2: 7584. [Indonesian]

Cilia DP, Sciberras A, Sciberras J, Pisani L. 2012. Terrestrial gastropods of the minor islets of the Maltese Archipelago (Mollusca Gastropoda). Biodivers J 3 (4): 543-554.

Coulson LA, Perrin C, Roberts DG, Minchinton TE, Ayre DJ. 2011. Can limited dispersal or biotic interaction explain the declining abundance of the whelk, Morula marginalba, at the edge of its range?. Biol J Linn Soc 103 (4): 849-862.

Dayrat B, Conrad M, Balayan S, White TR, Albrecht C, Golding R, Suzete RG, Harasewych E, Martins AMF. 2011. Phylogenetic relationships and evolution of pulmonate gastropods (Mollusca): New insights from increased taxon sampling. Mol Phylogenet Evol 59 (2): 425-437.

Dolorosa RG, Galon FD. 2014. Species richness of bivalves and gastropods in Iwahig River-Estuary, Palawan, the Philippines. Intl J Fish Aquatic Stud 2 (1): 207-215.

Donald KM, Preston J, Williams ST, Reid DG, Winter D, Alvarez R, Buge B, Hawkins SJ, Templado J, Spencer HG. 2012. Phylogenetic relationships elucidate colonization patterns in the intertidal grazers Osilinus Philippi, 1847 and Phorcus Risso, 1826 (Gastropoda: Trochidae) in the Northeastern Atlantic Ocean and Mediterranean Sea. Mol Phylogenet Evol 62 (1): 35-45.

El-Sorogy A, Kammar AE, Ziko A, Aly M, Nour H. 2013. Gastropod shells as pollution indicators, Red Sea coast, Egypt. J Afr Earth Sci 87: 93-99.

Fukumori H, Kano Y, 2013. Evolutionary ecology of settlement size in planktotrophic neritimorph gastropods. Mar Biol 161: 213-227.

Herbert GS, Merle D, Gallardo CS. 2007. A developmental perspective on evolutionary innovation in the radula of the predatory neo-gastropod family Muricidae. Am Malacol Bull 23 (1): 17-32.

Hong P. 2004. Effects of mangrove restoration and conservation on the biodiversity and environment in Can Gio district. In: Vanucci M (eds). Mangrove Management and Conservation: Present and Future. United Nations University Press, Tokyo.

Houbrick RS, 1992. Monograph of the genus Cerithium Bruguière in the Indo-Pacific (Cerithiidae: Prosobranchia). Smithson Contr Zool 510: $1-211$.

Igulu MM, Nagelkerken I, Dorenbosch M, Grol MGG, Harborne AR, Kimirei IA, et al. 2014. Mangrove habitat use by juvenile reef fish: Meta-analysis reveals that tidal regime matters more than biogeographic region. PLoS One 9: e114715. DOI: 10.1371 /journal.pone.0114715. 
Isroni W, Islamy RA, Musa M, Wijanarko P. 2019. Short Communication: Species composition and density of mangrove forest in Kedawang Village, Pasuruan, East Java, Indonesia. Biodiversitas 20 (6): 16881692.

Janssen R, Zuschin M, Baal C. 2011. Gastropods and their habitats from the Northern Red Sea (Egypt: Safaga) Part 2: Caenogastropoda: Sorbeochonca and Littorinimorpha. Ann Naturhist Mus Wien 113: 373-509.

Kumar RA, Jaiswar KS, Jahageerdar SP, Kumar A, Laxmi P. 2017. Comparative taxonomic evaluation of Thais species (Order: Gastropoda; Family: Muricidae) of Mollusca from Maharashtra coast of India. Indian J Geo-Mar Sci 44 (6): 1098-1104.

Lozouet P, Plaziat JC. 2008. Mangrove environments and mollusks. Abatan River, Bohol and Panglao Islands, Central Philippines. ConchBooks, Hackenheim.

Marshall DJ, Baharuddin N, Rezende E, Helmuth B. 2015. Thermal tolerance and climate warming sensitivity in tropical snails. Ecol Evol 5 (24): 5905-5919.

Mujiono N. 2016. Snail of the genus Clithon (Gastropoda: Neritidae) in Java: Status, distribution and phylogeny. Prosiding Seminar Nasional Masyarakat Biodiversitas Indonesia. Institut Pertanian Bogor, Bogor, 17 September 2016. [Indonesian]

Ng PK, Sivasothi N. 2002. A Guide to the Mangroves of Singapore. Singapore Science Centre, Singapore.

Nützel A, Hausmann I. 2016. Mollusc diversity and dominance in late Paleozoic and early Mesozoic marine environments. $19^{\text {th }}$ International Congress of Unitas Malacologica, Penang, 18-24 July 2016.

Okutani T. 2000. Marine Mollusks in Japan. Tokai University Press, Tokyo.

Ozawa T, Yin W, Fu CZ, Claremont M, Smith L, Reid DG. 2015 Allopatry and overlap in a clade of snails from mangroves and mudflats in the Indo-West Pacific and Mediterranean (Gastropoda: Potamididae: Cerithideopsilla). Biol J Linn Soc 114 (1): 212-228.

Pawar PR. 2012. Molluscan diversity in mangrove ecosystem of Uran (Raigad), Navi Mumbai, Maharashtra, west coast of India. Bull Environ Pharmacol Life Sci 1 (6): 55-59.

Periyasamy N, Srinivasan M, Balakrishnan S. 2012. Antimicrobial activities of the tissue extract of Babylonia spirata Linnaeus, 1758 (Mollusca: Gastropoda) from Thazhanguda, Southeast Coast of India Asian Pac J Trop Biomed 2 (1): 36-40.

Poppe GT. 2010. Volume III: Philippine Marine Mollusks. ConchBooks, Hackenheim.

Pratama IS, Hapsari P, Fahlevi SR. 2011. Macrobenthos community structure at rocky shore and seagrass ecosystem of Bama Coast, Baluran National Park. In: Nababan B (eds). Pertemuan Ilmiah Nasional Tahunan VIII ISOI. Hotel Sahid Jaya, Makassar, 25-27 September 2011. [Indonesian]

Radjasa OK, Putri MKD, Pringgenies D. 2012. Phytochemical and toxicity test of coarse extract of gastropod (Telescopium telescopium) on Artemia salina larvae. J Mar Res 1 (2): 58-66.

Reid DG, Dyal P, Williams ST. 2010. Global diversification of mangrove fauna: A molecular phylogeny of Littoraria (Gastropoda: Littorinidae). Mol Phylogenet Evol 55: 85-201.

Reid DG, Ozawa T. 2016. The genus Pirenella Gray, 1847 (Cerithideopsilla Thiele, 1929) (Gastropoda: Potamididae) in the Indo-West Pacific region and Mediterranean Sea. Zootaxa 4076 (1): $1-91$

Reid DG. 2014. The genus Cerithidea Swainson, 1840 (Gastropoda: Potamididae) in the Indo-West Pacific region. Zootaxa 3775 (1): 165

Shing YL, Jurgene HP, Dahdouh-Guebas F, McKee K, Jared OB, Stefano C, Karen D, Francois F, Nico K, Cyril M, Irving M, Nibedita M, Sydne R. 2014. Ecological role and services of tropical mangrove ecosystems: A reassessment. Glob Ecol Biogeogr 23 (7): 726-743.

Shukla ML. 2014. A Comparative Study of Macro Faunal Community of Natural and RestoredMangrove Sites between Mahi and Dhadhar River Estuaries of Gulf of Khambhat. [Dissertation]. Manonmaniam Sundaranar University, Baroda, India
Soekendarsi E. 2019. Gastropods and edible macroalgae. J Phys Conf Ser 1341 (2): 022018. DOI: 10.1088/1742-6596/1341/2/022018.

Solanki D, Kanejiya J, Gohil B. 2017. Ecological status of Pirenella cingulata (Gmelin, 1791) (Gastropod: Potamididae) in mangrove habitat of Ghogha Coast, Gulf of Khambhat, India. Cibtech J Zool 6 (2): 10-16.

Sri-aroon P, Butraporn P, Limsomboon J, Kerdpuech Y, Kaewpoolsri M, Kiatsiri S. 2005. Fresh-water mollusks of medical importance in Kalasin Province, Northeast Thailand. Southeast Asian J Trop Med Public Health 36 (3): 653-657.

Strong EE, Colgan DJ, Healy JM, Lydeard C, Ponder WF, Glaubrecht M. 2011. Phylogeny of the gastropod superfamily Cerithioidea using morphology and molecules. Zool J Linnean Soc 162 (1): 43-89.

Sun Q, Zhang S. 2014. A new species of Cerithium (Gastropoda: Cerithiidae) from the South China Sea. Chin J Oceanol Limnol 32 (5): 1118-1122.

Suprakto B. 2005. Study of Mangrove Dynamics in the South Coastal Area of Pamekasan Regency, East Java Province with Remote Sensing Data. MAPIN XIV Annual Scientific Meeting. Surabaya, 1415 September 2005. [Indonesian]

Suratno, Susilo VE, Doviyana V, Mujiono N. 2020. The diversity of Gastropoda in Meru Betiri National Park. J Phys Conf Ser. DOI: 10.1088/1742-6596/1465/1/012011.

Suresh M, Arularasan S, Srikumaran N. 2012. Screening on antimicrobial activity of marine gastropods Babylonia zeylanica (Bruguière, 1789) and Harpaco noidalis (Lamarck, 1822) from Mudasalodai, Southeast Coast of India. Intl J Pharm Pharm Sci 4: 552-556.

Tan SK, Clements R. 2008. Taxonomy and Distribution of the Neritidae (Mollusca: Gastropoda) in Singapore. Zool Stud 47 (4): 481-494.

Tan SK, Liu LL. 2001. Description of a new species of Thais (Mollusca: Neogastropoda: Muricidae) from Taiwan, based on morphological and allozyme analyses. Zool Sci 18 (9): 1275-1289.

Tan SK, Ng HE, Chan SY, Nguang LHS. 2019. A review of the recent Agaronia Gray, 1839 (Caenogastropoda: Olividae) of the Sundaic region, with description of a new species. Occasional Molluscan Pap 7: 1-19

Tapilatu Y, Pelasula D. 2012. Fouling organisms associated with mangrove in Ambon inner bay. Elektronik Jurnal Ilmu dan Teknologi Kelautan Tropis 4 (2): 267-279.

Tudu PC, Ghorai N, Yennawar P, Mohapatra A. 2017. Rediscover of Nerite snail Neripteron cornucopia (Gastropoda: Neritidae) after 180 years in India. Indian J Sci Res 13 (1): 208-211.

Vermeij GJ, Frey MA, Landau BM. 2009. The gastropod genus Nerita in the Neogene of tropical America. Cainozoic Res 6 (1-2): 61-70.

Voskuil R. 2018. The superfamily Olivoidea (Gastropoda: Neogastropoda). An illustrated chronologic catalogue of literature, taxa and type figures, 1681 to present. Version 3. R.P.A. Voskuil, Hulst.

Webb TJ. 2012. Marine and terrestrial ecology: Unifying concepts, revealing differences. Trends Ecol Evol 10: 535-541.

Wright JM, O'Connor WA, Parker LM, Ross PM. 2018. Predation by the endemic whelk Tenguella marginalba (Blainville, 1832) on the invasive Pacific oyster Crassostrea gigas (Thunberg, 1793). Molluscan Res 38 (2): 130-136.

Zeidan F, Baumgartner JN, Coghill RC. 2019. The neural mechanisms of mindfulness-based pain relief. PAIN Reports 4: 1-11.

Zhao D, Kong LF, Sasaki T, Li Q. 2019. Shell variations in the gastropod, Monodonta labio, in the North-western Pacific: The important role of temperature in the evolution process. J Mar Biol Assoc UK 99 (7): 19.

Zvonareva S, Kantor YI, Xinzheng L, Britayev T. 2015. Long-term monitoring of Gastropoda (Mollusca) fauna in planted mangroves in central Vietnam. Zool Stud 54 (39): 1-39.

Zvonareva S, Kantor YI. 2016. Checklist of gastropod molluscs in mangroves of Khanh Hoa province, Vietnam. Zootaxa 4162 (3): 401 437. 